\title{
IAMJ
}

INTERNATIONAL

AYURVEDIC

MEDICAL JOURNAL

Review Article

ISSN: 2320-5091

Impact Factor: 6.719

\section{CONCEPTUAL ANALYSIS OF SEX DETERMINATION OR LING NIRDHARANA IN AYURVEDA}

\author{
Pinki Maheshwari' ${ }^{1}$, Gyanadutta Pradhan², Sunita kumari ${ }^{3}$, Arvind Kumar ${ }^{4}$ \\ ${ }^{1}$ M.D. Scholar, ${ }^{2}$ M.D. Scholar, ${ }^{3}$ HOD and Reader, ${ }^{4}$ Lecturer \\ P.G. Department of Rachana Sharir SAC, Lucknow, Uttar Pradesh, India
}

Corresponding Author: DRPINKY.MAHESHWARI@hotmail.com

https://doi.org/10.46607/iamj1809042021

(Published online: April 2021)

Open Access

(C) International Ayurvedic Medical Journal, India 2021

Article Received: 24/03/2021 - Peer Reviewed: 31/03/2021 - Accepted for Publication: 01/04/2021

Check for updates

\begin{abstract}
All parents have a dream of be getting the healthy, intellectual and beautiful progeny this is also evident from the reference of the word like "Suputrakameeya" in classics. Ayurveda describes simple methods to produce a healthy offspring and the planning of which starts from the selection of partners. Many factors mentioned in Ayurveda towards the study of development of foetus including fertilization and sex determination, Ayurveda considered two basic factors in the development of human beings i.e., Shukra and Shonita it represents the sperm and ovum in modern medical science and which are responsible for the fertilization. Nearly all Acharyas like Charaka and Sushruta have recognised the three different types of sexes viz. Puman (male), Stri (female) and Napunsaka (hermaphrodite). In these contexts, Charaka clearly stated that dominance of Shonita during conception resulting procreation of female child and dominance of Shukra (sperm) leads to male child. The sex of an individual is determined by the $\mathrm{X}$ and $\mathrm{Y}$ chromosome. But sex determination mainly depends on the $\mathrm{Y}$ chromosome. It has been seen the individuals with a Y chromosome develop male characteristics and individuals without a Y chromosome develop female characteristics.
\end{abstract}

Keywords: Shukra, Shonita, Puman, Stri 


\section{INTRODUCTION}

The sages of ancient India gave the vision of many scientific facts about human body such discoveries are the fundamental aspects for the basis of other sciences in present scenario. Many factors mentioned in Ayurveda towards the study of development of foetus and genetics including fertilization and sex determination, Ayurveda considered two basic factors in the development of human beings i.e. Shukra and Shonita it represents that of sperm and ovum in modern medical science and which are responsible for the fertilization. In these contexts, Charaka clearly stated that dominance of Shonita during conception resulting procreation of female child and dominance of Shukra (sperm) leads to male child. The sex of an individual is determined by the $\mathrm{X}$ and $\mathrm{Y}$ chromosome. Chromosomal sex determination refers to the presence of two identical (XX) or two different (XY) chromosomes in females and males, respectively. This is due to the distinct content of the $\mathrm{X}$ and $\mathrm{Y}$ chromosomes in both genes and regulatory sequences, SRY (sex determining region $\mathrm{Y}$ ) being the key regulator Hormones (Anti Mullerian Hormone (AMH), testosterone secreted by the foetal testis (gonadal sexual dimorphism), impede Müller duct development, masculinize Wolff duct derivatives and are involved in testicular descent (hormonal sexual dimorphism). Furthermore, sex chromosome genes directly affect brain sexual dimorphism, and this may precede gonadal differentiation. As one must have knowledge of fundamental basics for which this study is undertaken.

Ayurvedic Review: Here four concepts of sex determination have been taken to describe as:

$1^{\text {st }}$ Concept: According to Ayurveda Garbha lingam or sex is the contribution of Shukra Dhatu and Artava. It is the predominance of 'Shukra' and 'Artava' particularly at the time of 'Shukra Artava Samyoga' (time of fertilization), which determines the sexuality according to Indian thoughts. Acharya Charaka and Sushruta both have recognised the three different types of sexes, viz., 'Puman' (male), 'Stri' (female) and 'Napunsaka'. He has also mentioned the factors playing role behind these three states of sexes. In his view, it is the predominance of Shukra lead to the formation of a male child, predominance of Artava leads to the formation of female child and their equality in strength leads to the formation of a Napumsaka. Dalhana has advanced the explanation of predominance of shukra and artava. He says that artava is four anjali and shukra one prasrati in quantity or artava will always be more in quantity than Shukra, but it is not so, here the quantity of pure Artava situated in uterus responsible for fertilization should be considered. However, occasionally due to over excitement etc. the quantity of ejaculated shukra (semen) may be more, or due to physiological depression it may be less which influences relative amount of shukra and artava. Citing the opinions of others, he has mentioned that instead of amounting the functional potency of shukra and artava influences the formation of sex.

Sharngdhara says that besides role of Shukra and Artava, the will of God is responsible for formation of sex.

$2^{\text {nd }}$ Concept: Yogaratnakara besides giving the importance of predominance of Shukra and Artava, has mentioned that from Dakshina-nadi the male child is born and from the left female child.

$3^{\text {rd }}$ Concept: Bhavamishra, gives a new view regarding birth of a male and female child and has recognised the way of insemination and the role of three distinct 'Nadees' is giving rise the male and female offspring. In his view, there are 'Sameerana', 'Chandramasi' and 'Gauri' three distinct 'Nadees' in a genital organ of a woman. The discharge of 'Virya' (semen) gets waste, if happens to fall in the mouth of the Sameerana; if it happens to fall in the mouth of Chandramasi, a second prominent $\mathrm{Nadi}$, the woman gets satisfied with little duration of orgasm and gives birth to a female child; if it happens to fall in the mouth of Gauri Nadi, a prominent one characterised to give birth to male.

$4^{\text {th }}$ Concept: When the coitus done on even days the born child would be male and with odd days it would be a female. On Chaturthi, Astami, Dashami and Dwadashi it would be male and on Panchami, Saptami, Navami and Ekadashi it would be a female. Trayodashi etc. are contraindicated dates for coitus. According to 
Vagbhata a person desirous of having an offspring of high qualities should have not coitus for three days in ritukala (up to $7^{\text {th }}$ day of menstruation). The child conceived on ekadashi and trayodashi would be napunsaka (hermaphrodite). The cause of birth of male or female on even or odd days respectively that on even days artava is less which increase on odd days.

\section{Modern Review:}

\section{System of Sex Chromosomes}

A sex determination system is a biological system that determines the development of sexual characteristics in an organism. When the presence of a chromosome that was involved in the determination of sex was noted, it was called the $\mathrm{X}$ chromosome. To differentiate it from the other chromosomes (which were not involved in the process of sex determination), it was also named the allosome (sex chromosome). Another chromosome, structurally different from the $\mathrm{X}$, but also involved in sex determination process was subsequently detected. It has been named the ' $\mathrm{Y}$ ' chromosome. In mammals, including humans, a normal female has two $\mathrm{X}$ chromosomes and a normal male has one $\mathrm{X}$ and one $\mathrm{Y}$ chromosome. The gametes of a female will have only the X chromosome. Therefore, females belong to the homozygotic sex. The gametes of the male will be in two groups: one group with the $\mathrm{X}$ chromosome and the other with the Y chromosome. Males belong to the heterozygotic sex.

\section{Correlation of First Concept}

- Shettles studied sperm cells to observe their differences. He theorized based on his observations is that Y-carrying sperm are lighter, smaller and have round heads.

- He also studied sperm in some rare cases where man had fathered either mostly male or mostly female children. In the cases where the man had mostly male kids, Shettles discovered that the man had far more $\mathrm{Y}$ - carrying sperm than $\mathrm{X}$ - carrying sperm.

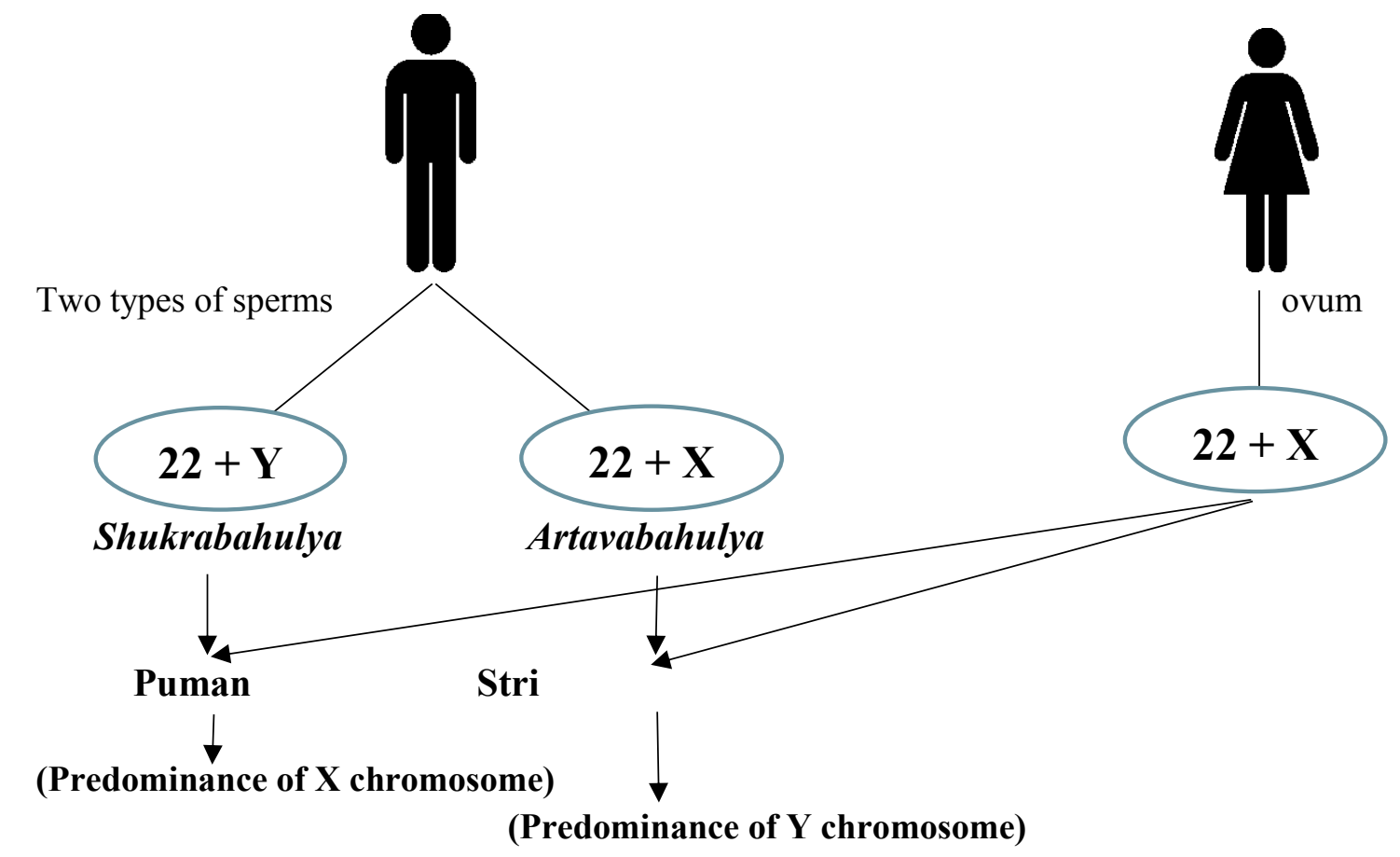




\section{Correlation of Second Concept}

The $\mathrm{X}$ and $\mathrm{Y}$ chromosomes in males act as homologous chromosomes during meiosis and pass into different gametes. Thus, males produce two types of gametes and are described as heterogametic i.e. (22+X) and (22+ Y) while the female which produces only one type of gamete is homogametic.

Otto schooner's theory: It is examined in research when right ovary ovulated ova will fertilize produces a male child as well as when left ovary ovulated ova will fertilize produces a female child. So left ovary ovulated ova more potent than right one.

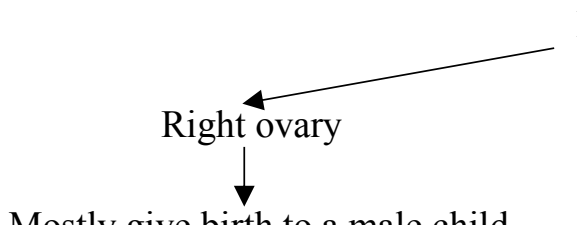

Mostly give birth to a male child
If ova ovulated

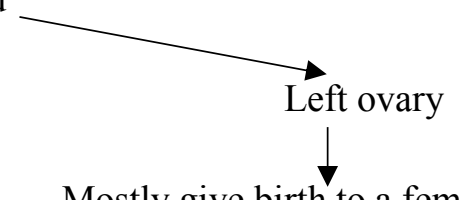

Mostly give birth to a female child

This method can be used after first pregnancy.

\section{Correlation of Third Concept}

- This method also correlated with Shettles method that male sperm tend to swim more quickly in alkaline environment like in the cervix and uterus and female sperm tend to survive longer in acidic conditions of the vaginal canal.

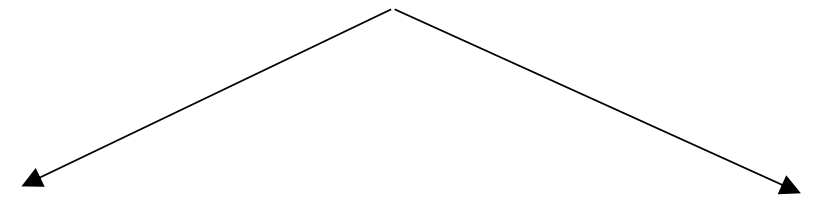

So, when sperm falling in upasthgeha having Gauri nadi (i.e. fornix part of the vagina very near to the cervix)

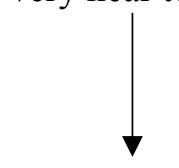

Male child
Thus when sperm falling in kandarpageha (mid vaginal canal) having chandramansi nadi

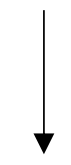

Female child

The discharge of 'Virya' (semen) gets waste, if happens to fall in the mouth of the Sameerana (introitus part of vagina).

- Here nadi can be correlated with the nerves also. This concept considered with sexual physiology as follows:

a) Erectile tissue (from introitus to the clitoris) controlled by the parasympathetic nerves of sacral plexus

Dilate the arteries of erectile tissue thus allow rapid accumulation of blood

Introitus tighten around the penis for sexual stimulation

b) Parasympathetic signals also pass to the bilateral Bartholin's glands secreates mucus immediately inside the introitus responsible for lubrication during sexual intercourse, although mucus also secreted from the vagina 
c) During the orgasm the peripheral muscles of the female contract rhythmically, which results in increase uterine and fallopian tube motility

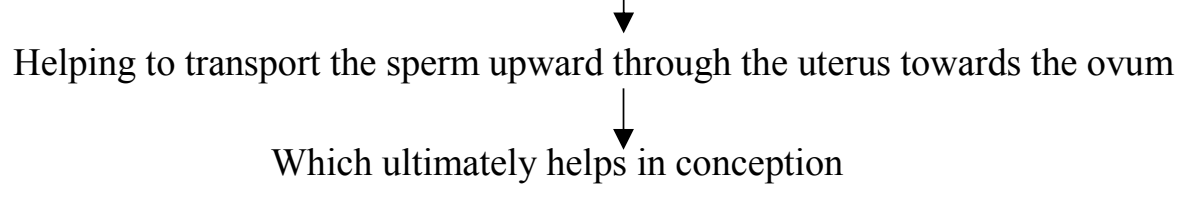

- Female orgasm seems to cause dilation of cervical canal for up to 30 minutes thus allowing easy transportation of sperms.

\section{Correlation of Fourth Concept (Scope for Further Study)}

Acharya Sushruta advises for expectant parents to indulge in sex during even days after the cessation of menstrual flow/days nearer to ovulation to get a male baby and odd days for those who are in expectation of female. According to Acharya Dalhana on even days there is less predominance of Rajah (X chromosome/ Rajotpadakbeejabhaga) and on odd days rajah is predominant. Hence, we obtain male baby on engaging in sex during even days of menstruation and female baby on odd days. One can conduct research work why and how Rajah varies in terms of predominance during these days.

\section{DISCUSSION}

The knowledge which our ancient seers is scientific and forms the basis of other sciences. We can find detailed description of Garbha Sharir in our classics. Grabha Sharir which deals with the developmental events that takes place during the Intra uterine life, which is nothing but Embryology of Modern Science. Garbha is defined as the union of Shukra and Shonita along with Atma. Modern science also explains that union of ovum and sperm (fertilisation) is the basic event necessary for it to be called an embryo later after consequent stages the resultant fertilised product is called foetus. Here Shukra and Shonita can be taken as sperm and ovum respectively. In our classics it is described that predominance of Shukra in the fertilized product gives birth to a male child, predominance of Shonita results in birth of a female child and predominance of both results in Napunsaka. As said in the earlier part of discussion that Shukra and Shonita are sperm and ovum respectively. Sperm contains $\mathrm{XY}$ chromosome and ovum contains XX chromosome. In the 1960s in the United States Landrum B. Shettles developed the Shettles method, which is a procedure for couples to use prior to and during an intercourse to increase their chances of conceiving a foetus of their desired sex. Shettles investigated whether he could differentiate Xcarrying sperm and Y-carrying sperm by their physical appearance. In the late 1960s Shettles examined over 500sperm specimens using a phase contrast microscope and concluded that the small, round-headed sperm contained male-producing $\mathrm{Y}$ chromosomes, or androsperm, while the large, oval-shaped sperm contained the female-producing $\mathrm{X}$ chromosomes, or gymnosperm. During his research, Shettles also noticed that most samples did not contain an equal number of both types of sperm. To analyse the potential effect that difference had on the actual sex outcome of a child, Shettles began checking the family history of the men who provided the sperm specimen. Although rare, he did find some instances of men whose semen contained significantly more round-headed androsperm in those cases, the men had a male-dominant family history Similarly, yet still rare, Shettles also found that men whose semen contained significantly more oval-shaped gymnosperm had produced more female children. So shukrabahulya can be correlated with Y-carrying sperms and artavabahulya with X-carrying sperms.

Shettles method also defines that male sperm tend to swim more quickly in alkaline environment like in the cervix and uterus and female sperm tend to survive longer in acidic conditions of the vaginal canal thus by this experimental theory we can justify the above third concept of three nadis in vaginal canal. 


\section{CONCLUSION}

Ayurveda a traditional life science, explains about the concept of sex determination in different ways which has similarities with the contemporary science. This shows that how well the embryological concepts were known to our Acharyas. But due to more advancement in medical technologies very detailed descriptions are seen in the modern science. We can predict that our Acharyas also had done repeated researches on these topics only then they were able to establish the concepts, they might even had done research on these concepts at higher level but we do not have such collections in our classics. By analysing the Review of the concerned topic, it is concluded that there are similarities between both the sciences about the concept of Sex determination. Shukra is considered as sperm having Y chromosome and Shonita is considered as sperm as having $\mathrm{X}$ chromosome and also with ovum having $\mathrm{X}$ chromosome.

\section{REFERENCES}

1. Rorvik, David Michael and Landrum, B. Shettles. How to Choose the Sex of Your Baby: The Method Best Supported by Scientific Evidence. New York City: Broadway Books, 2006.https://archive.org/details/howtochoosesexof00sh et [27] (Accessed March 27, 2018)

2. Agnivesa, Caraksamhita, edited with Vidyotiniteeka by Kashinath Sashtri and Gorakhanath Chaturvedi, vol-1, Sharir Sthana-2, Varanasi, Chaukhamba bharti publication, 2005; pg no 840

3. Sushruta, Sushruta Samhita of Maharshi Sushruta, Kaviraja Ambikadutta Shashtri, edited with AyurvedaTattva-Sandipika foreword by Dr. Pranajivana Manekchanda Mehta Chaukhambha Sanskrit Sansthan reprint edition, 2008, pg no 26.

4. Agnivesa, Caraksamhita, edited with Lakshmidhar dwiwedi, part 2, Sharir Sthana- 2 Chaukhamba Krishnadas Academy, Varanasi,2008, pg no 1012

5. Sharangadhara, Sharangadhara samhita with the commentary Aadhamalla's dipikas and kasirama's gudhartha-dipika edited by Pt. Parashuramshatri Vidyasagar, introduction by Prof. C.B. Jha, 1st edition, published by Chaukhamba Surbharati Prakashan, Varanasi.2006
6. Vaidya Lakshmipati Shastry-Yogaratanakara, Chaukhamba Surbharati Prakashan, Varanasi, 4th edition, 1998.

7. Varrier, Vaidyaratnam PS: Ashthanga Shareeram, 2nd edition The Arya Vaidya Sala, Kottakal, Brihatshareeram Varrier, Garbhavkranti 14

8. Bhava Mishra, Bhavprakash Samhita, $5^{\text {th }}$ edition Vidyotini Commentary by Brahma Shankar Shastri, Chaukhamba Sanskrit Series, Varanasi, 1969.

9. Bhishagacharya Harishastri Paradkar Vaidya with Sarvanga Sundara: Ashtang Hridaya of Acharya Vagbhat, 8th edition, commentary of Arunadatta, Chaukhamba Orentalia Varanasi, 1998.

10. Singh Inderbeer, human anatomy, 6th edition, Jaypee brothers' medical publishers, vol. 3, pg no 491

11. Guyton, human physiology, $6^{\text {th }}$ edition, page no. 1023

12. Rorvik, David Michael and Landrum B. Shettles. Your Baby's Sex: Now You Can Choose. New York City: Dodd, Mead and Company, 1970. (Accessed March 27, 2018).

\section{Source of Support: Nil Conflict of Interest: None Declared}

How to cite this URL: Pinki Maheshwari et al: Conceptual Analysis Of Sex Determination Or Ling Nirdharana In Ayurveda. International Ayurvedic Medical Journal \{online\} 2021 \{cited April, 2021\} Available from: http://www.iamj.in/posts/images/upload/799 804.pdf 